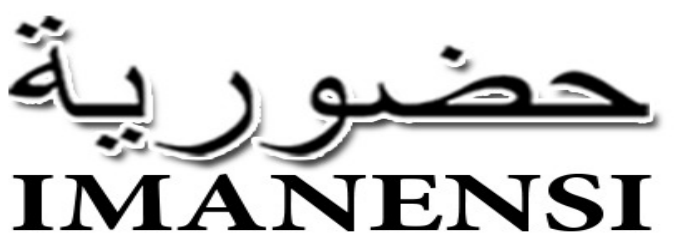

Jurnal Ekonomi, Manajemen, dan Akuntansi Islam

Vol 5, No 2, September 2020, H1mn. 69-78

\title{
Mengungkap fenomena anggaran perubahan dan partisipasi masyarakat akibat Pandemi Covid 19
}

\author{
Evi Grediania,1,* \\ aAkademi Akuntansi YKPN, J1. Balapan Jl. Gagak Rimang No.2-4, \\ Yogyakarta, 55222, Indonesia. \\ 1gredianie@gmail.com* \\ * correspondence author
}

10.34202/imanensi.5.2.2020.69-78.

\begin{abstract}
Abstrak
Penelitian ini bertujuan untuk mengungkap fenomena anggaran perubahan dan partisipasi masyarakat wilayah Kecamatan Pakualaman akibat pandemi COVID-19. Jenis penelitian kualitatif dan analisis dilakukan dengan intepretasi, pengorganisasian data, membuat memo, dan pemaknaan transkrip wawancara dari enam informan. Hasil penelitian menunjukkan bahwa dampak pandemi COVID-19 menghentikan belanja atau nol belanja (kecuali belanja tertentu). Masyarakat berpartisipasi secara swadaya dan mandiri untuk segera bergerak bersama dalam kegiatan pencegahan penyebaran COVID-19, walaupun anggaran perubahan dari APBD belum dapat direalisasikan untuk penanganan penyebaran COVID-19. Kondisi pandemi telah menyatukan warga untuk bergotong-royong bersama tanpa banyak intervensi pemerintah secara materi.
\end{abstract}

Kata Kunci: Anggaran; Partisipasi Masyarakat; Kebijakan; Gotong Royong

\begin{abstract}
This study aims to reveal the phenomenon of budget changes and community participation in the Pakualaman District due to the COVID-19 pandemic. Qualitative research and analysis was carried out by interpreting, organizing data, making memos, and interpreting interview. The research results show that the impact of the pandemic has stopped spending or zero spending (except certain shopping). The community participates independently and independently to immediately move together in activities to prevent the spread of COVID-19, even though the revised budget from the $A P B D$ cannot be realized for handling the spread of COVID-19. Pandemic conditions have brought together citizens to work together without much material government intervention.
\end{abstract}

Keyword: Budgets; Public Participation; Policies; Gotong Royong. 


\section{PENDAHULUAN}

Anggaran digambarkan sebagai ekspresi kuantitatif formal dari rencana strategi organisasi, memberikan manajer dan bawahan arahan untuk memastikan upaya dan motivasi akurat menuju pencapaian tujuan dan sasaran strategis (Kenno, Lau, Sainty, \& Boles, 2020). Anggaran merupakan komponen utama dari perencanaan dan pengendalian (Grediani \& Sugiri, 2010). Anggaran yang berkaitan dengan sektor publik, dikenal dengan Anggaran Pendapatan dan Belanja Nasional/Daerah (APBN/D). Perubahan APBD merupakan program yang dilakukan secara rutin oleh pemerintah daerah, sebagai upaya untuk menjalankan penyesuaian yang terjadi (Kurniawan \& Arza, 2019) dan memengaruhi anggaran di massa mendatang (Pessina \& Sicilia, 2012). Setiap daerah memungkinkan memiliki peraturan perubahan anggaran yang berbeda dan konsep dari pemerintah daerah lainnya, namun demikian harus mengacu pada Undang-Undang dan peraturan yang dikeluarkan oleh Pemerintah Pusat (Widyaningrum et al., 2019).

Perubahan anggaran dan penganggaran dapat dipengaruhi oleh kondisi sosial, ekonomi lokal (Pessina \& Sicilia, 2012; Widyaningrum et al., 2019). Pemerintah Daerah harus segera mengantisipasi penyebaran COVID-19 di wilayah, dengan memanfaatkan anggaran yang sudah difiksasi awal tahun. Anggaran perubahan yang biasanya dilaksanakan pertengahan tahun, harus digeser maju akibat pandemi COVID-19. Partisipasi masyarakat merupakan salah satu aspek utama penggunaan dana (Sofianto, 2017). Partisipasi masyarakat di wilayah diantaranya berkegiatan kelompok dan berkontribusi pada pembangunan wilayah (Krisnawati et al., 2019). Keberhasilan sebuah proyek pembangunan dan perencanaan pembangunan dipengaruhi oleh komponen partisipasi masyarakat (Dewi \& Adi, 2019).

Pemerintahan Pusat maupun Pemerintahan Daerah memerlukan partisipasi dalam pemberdayaan masyarakat guna pengembangan, pertumbuhan dan pembangunan suatu wilayah. Dengan menyebarnya pandemi Covid 19 keseluruh negara, termasuk Indonesia, tindakan pencegahan dilakukan pemerintah. Pencegahan level masyarakat diantaranya adalah pembatasan interaksi fisik (psysical distancing) dan pembatasan sosial (social distancing) (Kemenkes, 2020). Berkaitan dengan pembatasan sosial dan interaksi fisik, maka aktivitas kepentingan pribadi seperti membeli kebutuhan pokok dan keperluan lainnya akan berkurang intensitasnya bahkan terhenti sementara. Begitu juga secara otomatis aktivitas yang melibatkan peranserta dalam pemberdayaan masyarakat di wilayah akan tertunda atau berhenti. Kondisi ini mengakibatkan target kinerja pemerintahan tidak optimal. Di sisi lain, Pemerintah Pusat harus segera membuat aturan terkait penanganan COVID-19 dan penyesuaian anggaran. Disinilah arti pentingnya anggaran untuk keberhasilan pembangunan, guna memperbaiki kehidupan masyarakat.

Penelitian dilakukan karena tiga hal. Pertama, fenomena pandemi COVID19 merupakan suatu kejadian baru dan luar biasa bagi bangsa Indonesia dan seluruh dunia yang mempengaruhi faktor makro dan mikro. Kedua, adanya tanggap darurat bagi wilayah Kota Yogyakarta. Ketiga, adanya perubahan anggaran yang berdampak terhadap partisipasi masyarakat. Tujuan penelitian ini untuk mengungkap fenomena anggaran perubahan dan partisipasi masyarakat wilayah Kecamatan Pakualaman akibat pandemi COVID-19. Penelitian ini memberikan kontribusi bagi pengembangan ilmu pengetahuan dibidang akuntansi manajemen, sistem pengendalian manajemen, corporate governanvce, dan akuntansi sektor publik, diharapkan 
menemukan kaitan dan nilai baru bagi anggaran perubahan berkaitan dengan suatu kejadian khusus seperti Pandemi Covid 19.

\section{METODE}

Metode penelitian menggunakan pendekatan kualitatif. Sumber data diperoleh dari wawancara dengan enam informan yaitu 3 orang unsur pimpinan di wilayah kecamatan Pakualaman Kota Yogyakarta (I1, I2 dan I3), 1 orang unsur perencanaan, evaluasi dan pelaporan (I4), 2 orang unsur lembaga pemberdayaan masyarakat (I5 dan I6). Informan pertama, kedua dan ketiga memiliki pengalaman dalam membuat kebijakan terkait pandemi di wilayah Kecamatan Pakualaman Informan keempat memiliki pengalaman teknis membuat Dokumen Pelaksanaan Anggaran (DPA), Anggaran Perubahan dan menguasai tentang aturan-aturan pembuatan anggaran. Informan kelima dan keenam memiliki pengalaman yang berbeda terkait dengan kegiatan dan partisipasi masyarakat dalam pencegahan dan penanggulangan penyebaran pandemi virus COVID-19 serta pengalaman memimpin kelembagaan lebih dari lima tahun.

Peneliti melakukan intepretasi data dengan pengorganisasian data, membuat memo, pemaknaan wawancara. Selanjutnya teknis analisis data terdiri dari empat tahap (Nakpodia \& Adegbite, 2018; Syailendra \& Hamidah, 2019) yaitu (1) Peneliti menjabarkan fenomena berdasarkan wawancara yang telah direkam; (2) mencari tema yang ada dalam deskripsi data hasil wawancara berupa fenomena anggaran perubahan dan partisipasi masyarakat akibat pandemi ovid 19; (3) Data mentah akan diolah menjadi sebuah kategori menyusun tema; (4) menyandingkan temuan penelitian dengan Peraturan Pemerintah Nomor 45 Tahun 2017 sebagai parameter.

\section{HASIL DAN PEMBAHASAN}

\subsection{Pandemi virus COVID-19 mempengaruhi anggaran perubahan dan partisipasi masyarakat.}

Fenomena pandemi virus COVID-19 secara umum memberikan dampak terhadap semua sendi kehidupan, baik sosial, budaya, ekonomi, politik, hukum dan pertahanan keamanan. Kota Yogyakarta tidak terkecuali juga mengalami hal yang sama, sehingga memerlukan sistem untuk penanggulangan dampak tersebut supaya Organisasi Perangkat Daerah Wilayah Kecamatan Pakualaman bisa melakukan eksekusi kebijakan. Pada tanggal 2 Maret 2020. Presiden Joko Widodo mengeluarkan pengumuman bahwa di Indonesia ada kasus positif COVID-19. Informasi ini menjadi pijakan kebijakan selanjutnya yang akan dilakukan oleh Pemerintahan Pusat dan Pemerintahan Daerah. Pada tanggal 31 Maret 2020 Presiden mengeluarkan Keputusan Presiden Nomor 11 Tahun 2020 tentang penetapan status kedarutatan kesehatan masyarakat, ditindaklanjuti pada tanggal 4 April 2020 Kepolisian Republik Indonesia mengeluarkan Maklumat Polri tentang physical distancing.

Pemerintahan Daerah Istimewa Yogyakarta pada tanggal 20 Maret 2020 juga segera merespon informasi yang sudah dikeluarkan Presiden dengan menetapkan status tanggap darurat sampai dengan tanggal 20 Mei 2020. Pemerintahan Kota Yogyakarta pada tanggal 16 Maret 2020 mengeluarkan Surat Edaran tentang pencegahan COVID-19 dan tanggap darurat. Pada tanggal 26 Maret 2020 Walikota Yogyakarta selaku Ketua Gugus Tugas mengeluarkan arahan dan himbauan untuk aparatur sipil negara agar bekerja dengan sistem bergantian dan terjadwal, yaitu sebagian bekerja dari rumah dan sebagian di kantor untuk mengurangi dan menghentikan 
penyebaran COVID-19. Pada tanggal 2 April 2020 Walikota Yogyakarta mengeluarkan Surat Edaran Nomor 130/1397/SE/2020 tentang Penyusunan Pra Perubahan Renja Perangkat Daerah Tahun 2020 bagi Organisasi Perangkat Daerah dan Unit Kerja Pemerintahan Kota Yogyakarta.

Penanganan COVID-19 di Kecamatan Pakualaman Kota Yogyakarta mengikuti arahan yang diberikan oleh Walikota Yogyakarta sebagai Ketua Satuan Gugus Tugas Kota Yogyakarta, seperti penjelasan Informan pertama (I1).

"Untuk Pakualaman adalah salah satu anggota Gugus Tugas, arahan dilakukan oleh Ketua Satuan Gugus Tugas, beserta jajarannya terkait bisa mengurangi penyebaran COVID-19, begitu...".

Pernyataan I1 dalam sisi obyektivitas tugas dan pemahaman, juga terdapat pada pernyataan Informan kedua (I2).

"Terkait dengan penangananan di Pemerintah Kota mengikuti arahan Bapak Walikota selaku Ketua Gugus Tugas tingkat Kota dan yang membantu adalah di tingkat Kecamatan. Didalamnya sebagai pengarah Ketua Kesi (Kelurahan Siaga), dibantu Ketua Kampung, Lembaga LPMK (Lembaga Pemberdayaan Masyarakat Kelurahan), PKK (Pemberdayaan Kesejahteraan dan Keluarga), Kesi masing-masing RW (Rukun Warga), bergerak".

Kebijakan penanganan dalam menanggulangi pandemi COVID-19 di Kecamatan Pakualaman pada saat ini oleh I1 dinyatakan bahwa

\begin{abstract}
"Penanganan menyesuaikan, administrasi perkantoran dilaksanakan seperti biasa, bayar telepon, listrik, tidak terpengaruh. Kegiatan yang melibatkan masyarakat dibatasi, ada maklumat dari Kapolri ... 24 Maret, sejak itu dibatasi. Anggaran yg melibatkan masyarakat banyak ditunda sambil menunggu arahan dari Pemerintah Kota. Massa tanggap darurat, mengoptimalkan pembelian masker, handsantiizer, desinfektan untuk internal kantor Pemerintah Kecamatan ... Masyarakat sekarang sudah bergerak terlebih dahulu, memang kesannya Pemerintah Kota agak terlambat."
\end{abstract}

Kebijakan penanganan dalam kaitan penggunaan anggaran tidak bisa fleksibel, namun dapat menyesuaikan dengan kondisi wilayah masingmasing. Pernyataan Informan kedua (I2) dan Informan ketiga (I3) memberikan gambaran kebijakan penanganan di wilayah. Pernyataan I2 dan I3:

"Bentuk penanganannya dan pencegahan antara lain masingmasing RW (Rukun Warga) adalah penyemprotan. Lembaga mitra kelurahan melakukan pencerahan, penyuluhan terkait pencegahan COVID-19. Satuan Tugas Kelurahan menunggu perintah Gugus Tugas tingkat Kecamatan PA bergerak bersama satgas yang dibentuk ... tidak bergerak sendiri-sendiri, kami memberi masukan lewat satgas, laporan, pendataan pendatang”. 
"Di Purwokinanti ada tempat cuci tangan, sudah dibuat beberapa, kegiatan gentongisasi diubah, nanti akan berubah dengan keramik dan pralon ... kegiatan lain dihentikan, koordinasi masih baik melalui media sosial, WA, atau langsung koordinasi dengan 3 sampai 5 orang."

Pandemi COVID-19 menyebabkan kegiatan kemasyarakatan terhambat, dan penggunaan anggaran harus disesuaikan. Kebijakan penanganan pandemi COVID-19 yang sudah berjalan belum maksimal, dari pernyataan obyektivitas pimpinan wilayah Kelurahan dan Kecamatan memberi gambaran bahwa anggaran yang ada tidak bisa langsung digunakan untuk penanganan Covid-19 karena tidak sesuai dengan alokasi anggaran yang telah ditetapkan dalam anggaran belanja pemerintah daerah. Kondisi pandemi menyebabkan adanya penurunan pendapatan di wilayah Kota Yogyakarta sehingga perlu dilakukan langkah khusus mengatasi hal tersebut. Pernyataan I1 memberi gambaran anggaran perubahan.

“...Informasi dari Walikota, anggaran kota defisit, terkoreksi banyak, pajak hotel, restoran sedikit ... Perubahan Anggaran seharusnya sekitar bulan Juli-Agustus, maka diajukan bulan Maret sudah mulai dibahas, karena situasi darurat tersebut. Anggaran yang tidak berkaitan dengan penanganan COVID nanti bisa ditunda atau rasionalisasi. Rasionalisasi minimal 25\% ... kondisi buruk, maka kita bisa memotong sampai 50\% ... Semangatnya pemotongan anggaran adalah untuk membantu penanganan COVID"

Pernyataan I2 memberi gambaran anggaran berjalan dan anggaran perubahan sebagai bagian dari rasionalisasi wilayah Kecamatan Pakualaman.

"Anggaran triwulan satu sebagian besar sudah terlaksana ... Anggaran diambil alih untuk mendukung pencegahan COVID. Anggaran Perubahan kedepan dirasionalisasi sampai 50\%. Kami harus menata dulu, kegiatan yang bisa diubah untuk mendukung kegiatan penanganan COVID, hampir separo tinggal 400 juta, utamanya untuk recovery-nya, peningkatan ekonomi..."

Kelurahan Purwokinati sebagai bagian wilayah Kecamatan Pakualaman memberikan gambaran pelaksanaan anggaran dan rencana kegiatan dalam anggaran perubahan. Obyektivitas kebijakan yang dilakukan di wilayah memberikan pemahaman bahwa fenomena pandemi COVID-19 sangat mempengaruhi anggaran perubahan di wilayah Kecamatan Pakualaman. Pernyataan I3 memberikan gambaran kebijakan yang dilakukan akibat dampak yang ditimbulkan.

"Anggaran ada realokasi, pembahasan anggaran harus menghapus kegiatan yang tidak mendukung penanganan COVID19. Untuk Dana Kelurahan sebesar Rp350 juta harus tetap sesuai Pagu (alokasi anggaran yang ditetapkan berdasarkan anggaran belanja pemerintah daerah ... Selama ini pembiayaan beli masker dan handsanitizer tidak menggunakan anggaran sementara swadaya, beli alat mandiri dari bantuan warga." 
Pembahasan anggaran perubahan pada tanggal 16 April masih berlangsung di Kantor Kecamatan Pakualaman untuk dievaluasi oleh Bappeda (Badan Perencanaan Pembangunan Daerah). Informan keempat (I4) memberikan gambaran tentang anggaran perubahan Kecamatan Pakualaman.

"Pelatihan pembuatan masker bentuk pelatihan online, dirumah masing-masing. Kita meminta supaya PAP tidak dikurangi karena berkaitan juga dengan pihak eksternal. PAP digunakan untuk pengeluaran uang piket, honor tenaga bantuan, honor jasa kebersihan. Nilai sekitar 400 juta. Gedung kantor sudah proses kontrak dibulan ini, segera dilaksanakan. Angka tetap 185 juta. Perkembangan setelah diseminasi akan segera dilaporkan. Anggaran semula sebesar Rp3,7 Milyar menjadi 1,1 Milyar dengan rasionalisasi sekitar 31,5 persen".

Akibat social distancing, kegiatan pengumpulan massa tidak ada, konsekuensinya kegiatan masyarakat yang bersumber dari anggaran pemerintah Kecamatan Pakualaman tertunda bahkan terhenti. Pernyataan dari Informan kelima (I5) dan keenam (I6) sebagai perwakilan lembaga kemasyarakatan di wilayah Kecamatan Pakualaman menggambarkan hal tersebut.

"Sementara kegiatan terhenti, masih social distancing. Kegiatan tahun 2020 dialihkan untuk penanggulangan COVID, kegiatan fisik juga diarahkan ke penangangan COVID". (I5)

"Secara umum berhenti semua, dampaknya luar biasa, khususnya Purwokinanti. Misalnya rapat 2 kali saja dan sudah terlaksana, yang jatahnya 9 kali sampai Oktober. Kegiatan kemasyarakatan otomatis saat ini terhenti”. (I6)

Dari semua pernyataan I1, I2, I3, I4, I5 dan I6 menyiratkan bahwa pandemi COVID-19 mengakibatkan dampak bagi kegiatan masyarakat yang bersumber dari anggaran pemerintah daerah. Menyebabkan adanya social distancing sehingga mempengaruhi penurunan pendapatan pemerintah daerah, dan memberikan efek domino mengharuskan adanya anggaran perubahan. Anggaran perubahan terpaksa dilakukan agar pemerintah daerah dapat melakukan kegiatan yang berkaitan dengan penanganan dan penanggulangan penyebaran COVID-19. Anggaran perubahan mengalami pemangkasan yang sangat tajam. Pada saat penulisan artikel ini tanggal 21 April 2020, Tim Anggaran Pemerintah Daerah menginstruksikan bahwa Sisa Anggaran yang belum dilaksanakan sampai tanggal 21 April 2020 dirasionalisasi sebesar 100\% kecuali untuk Belanja Listrik, Jasa Keamanan, Jasa Orang Perseorangan/Naban, Jasa Kebersihan, Premi Asuransi Kesehatan, Barang dan Jasa BLUD, Barang dan Jasa Dana BOS, Barang dan Jasa Dana BOSDA, Modal BLUD, Modal Peralatan dan Mesin Dana BOS, Modal Aset Tetap Dana BOS, Modal Gedung dan Bangunan Dana BOS, Modal Pelaksanaan BOSDA.

\subsection{Pemaknaan Partisipasi Masyarakat Akibat Pandemi COVID-19}

Partisipasi Masyarakat menurut Peraturan Pemerintah Nomor 45 Tahun 2017, dalam ketentuan umum pasal (1), Partisipasi Masyarakat adalah peran serta Masyarakat untuk menyalurkan aspirasi, pemikiran, dan 
kepentingannya dalam penyelenggaraan pemerintahan daerah. Masyarakat adalah orang perseorangan warga negara Indonesia, kelompok masyarakat, dan/atau Organisasi Kemasyarakatan. Organisasi Kemasyarakatan adalah organisasi kemasyarakatan sebagiamana dimaksud dalam peraturan perundang-undangan yang mengatur mengenai Organisasi Kemasyarakatan.

Pasal 13 ayat (1) dalam melaksanakan pembangunan daerah, Pemerintah Daerah mendorong Partisipasi Masyarakat dalam bentuk kemitraan. Ayat (2) Partisipasi Masyarakat sebagaimana dimaksud pada ayat (1) dapat dilakukan dalam bentuk pemberian hibah dari Masyarakat kepada Pemerintah Daerah dalam bentuk uang, barang, dan/atau jasa sesuai dengan peraturan perundang-undangan. Pasal 18 ayat (1) Pemerintah Daerah memberikan dukungan penguatan kapasitas kelompok masyarakat dan/atau Organisasi Kemasyarakatan untuk berpartisipasi secara efektif dalam penyelenggaraan pemerintahan daerah. Ayat (2) Dukungan penguatan kapasitas sebagaimana dimaksud pada ayat (1) dilakukan dalam bentuk penyuluhan, pendidikan dan pelatihan, dan pendampingan sesuai dengan ketentuan peraturan perundang-undangan.

Pernyataan semua informan (I1, I2, I3, I4, I5 dan I6) berkaitan dengan partisipasi warga masyarakat termasuk lembaga dalam hal penanganan dampak pandemi COVID-19 seperti pernyataan berikut:

"Masyarakat sudah bergerak terlebih dahulu, yang sadar terhadap penularan penyakit kemudian beli masker, handsanitizer, sabun”. (I1)

"Lembaga sosial masyarakat dengan Lurah, Camat, langsung tanggap, aktivitas mandiri dilaksanakan bersama-sama, dari beberapa lembaga masyarakat, saiyeg saekoproyo untuk mengatasi dampak menika. Namun dampak sektor ekonomi juga ada, inisiatif unsur pimpinan wilayah untuk membagi sembako, untuk warga yang terdampak. Komunitas hotel memberikan wastafel untuk diletakkan dipinggir jalan. Alhamdulillah di Purwokinanti sudah ada kesadaran membantu menyumbangkan apa saja untuk penangangan COVID-19”. (I6)

"Warga yang mampu, kita minta untuk membantu, ada forum hotel raketang sithik kalau untuk membantu masih bisa, termasuk pengusaha lain kita ajak untuk membantu. Bantuan berupa masker, gerabah tempat cuci tangan paket sembako”. (I5)

"Masing-masing RW melakukan penyemprotan desinfektan secara mandiri, memasang wastafel di pinggir jalan". (I2)

"Penyemprotan desinfektan keliling kampong, warga masyarakat memberikan bantuan sembako bagi warga terdampak". (I3)

Berdasarkan pernyataan dari informan memberikan gambaran bahwa walaupun semua warga masyarakat mengalami dampak dari pandemi COVID19, namun tetap ada rasa kepedulian saling berpartisipasi agar penyebaran COVID-19 menurun. Partisipasi masyarakat yang dilakukan mempunyai makna yang sama sesuai dengan PP No.45 Tahun 2017 (Republik Indonesia, 2017). Bentuk partisipasi masyarakat yang ada di wilayah Kecamatan Pakualaman untuk warga terdampak berupa: (a) barang, yaitu pemberian 
hibah masker, tempat cuci tangan (berupa gentong, wastafel keramik, ember, dl1), sabun, handsanitizer, sembako untuk didistribusikan bagi warga terdampak langsung ke seluruh wilayah kecamatan; (b) jasa yaitu tenaga untuk mendistribusikan bantuan dan tenaga penyemprotan desinfektan di masing-masing wilayah RT, RW dan Kampung di wilayah Kecamatan Pakualaman.

\section{SIMPULAN}

Penelitian ini memberikan simpulan bahwa pandemi virus COVID-19 memberikan dampak terhadap aktivitas kegiatan kemasyarakatan dan anggaran perubahan pemerintah daerah. Salah satu cara yang dilakukan Pemerintah Kota Yogyakarta adalah harus segera melakukan pembahasan anggaran perubahan bagi Organisasi Perangkat Daerah wilayah Kota Yogyakarta. Anggaran perubahan yang seharusnya bulan Juli-Agustus, harus dimajukan pada akhir bulan Maret sampai dengan bulan April. Rasionalisasi anggaran minimal sebesar 25\% dari Dokumen Pelaksanaan Anggaran (DPA) saat ini, bahkan sampai harus menghentikan belanja atau nol belanja (kecuali belanja tertentu) mulai 21 April 2020. Pada saat keadaan darurat, anggaran perubahan dari APBD belum dapat direalisasikan untuk penanganan penyebaran COVID-19 memaksa masyarakat untuk segera bergerak bersama dalam kegiatan-kegiatan pencegahan penyebaran COVID19 berupa kegiatan-kegiatan yang dilaksanakan secara swadaya dan mandiri seperti penyemprotan disinfektan, pembuatan wastafel, pengadaan masker, pemberian sembako. Keadaan darurat telah menyatukan warga untuk bergotong-royong bersama tanpa banyak intervensi pembangunan oleh pemerintah secara materi. Kegiatan-kegiatan pencegahan COVID-19 banyak dilakukan oleh masyarakat memiliki makna bahwa tanpa intervensi anggaran dari pemerintah, masyarakat sebenarnya sampai saat ini masih mampu melakukan pencegahan penyebaran COVID-19 secara mandiri.

\section{REFERENSI}

Bastian, I., Winardi, R. D., \& Fatmawati, D. (2018). Metoda Wawancara. Research Gate, (September), 1-42.

Belal, A. R., Cooper, S. M., \& Khan, N. A. (2015). Corporate environmental responsibility and accountability: What chance in vulnerable Bangladesh? Critical Perspectives on Accounting, 33, 44-58. https://doi.org/10.1016/j.cpa.2015.01.005

Chua, W. F. (1986). Radical Developments in Accounting Thought. American Accounting Association, 61(4), 601-632.

Creswell, J. W. (2014). Research Design_Qualitative, Quantitative, and Mixed Method Approaches: SAGE Publication.

Dewi, D. E., \& Adi, P. H. (2019). Transparansi, Akuntabilitas, Partisipasi Masyarakat Dalam Pengelolaan Keuangan Dana Desa Terhadap Pembangunan Desa di Desa Candirejo Kecamatan Priapus Kabupaten Semarang. Edunomika, 3(2), 287-299.

Farooq, M. B., \& Villiers, C. de. (2017). Telephonic qualitative research interviews: when to consider them and how to do them. Meditary Accountancy Research, 25(2), 291-316. https://doi.org/10.1108/MEDAR10-2016-0083

Grediani, E., \& Sugiri, S. (2010). Pengaruh Tekanan Ketaatan dan TanggungJawab Persepsian Pada Penciptaan Budgetary Slack. SNA XIII, $1-28$.

Kemenkes. (2020). Pedoman pencegahan dan pengendalian coronavirus 
disease (covid-19).

Kenno, S., Lau, M., Sainty, B., \& Boles, B. (2020). Budgeting, strategic planning and institutional diversity in higher education. Studies in Higher Education, (January),

$1-15$. https://doi.org/10.1080/03075079.2019.1711045

Kouchaki, M., Smith-crowe, K., Brief, A. P., \& Sousa, C. (2013). Seeing green: Mere exposure to money triggers a business decision frame and unethical outcomes. ORGANIZATIONAL BEHAVIOR AND HUMAN DECISION, 1-9. https://doi.org/10.1016/j.obhdp.2012.12.002

Krisnawati, N. made G., Astrawan, G., Putri, P. R., Marleni, N. M. S., Kristian, N. P., \& Krisantina, N. M. A. P. (2019). Optimalisasi Partisipasi Masyarakat Dalam Pengelolaan Keuangan Desa Bresela Kecamatan Payangan Kabupaten Gianyar. Jurnal Ilmiah Akuntansi Dan Humanika, 9(1), 37-46.

Kurniawan, A., \& Arza, F. I. (2019). Pengaruh FiscalSstress ,Vvarians Anggaran dan Perubahan Sisa Lebih Perhitungan Anggaran Terhadap Perubahan Anggaran Belanja Pada Pemerintah Daerah. Jurnal Eksplorasi Akuntansi, 1(3), 1275-1292.

Mahmood, Z., Kouser, R., Ali, W., Ahmad, Z., \& Salman, T. (2018). Does Corporate Governance Affect Sustainability Disclosure? A Mixed Methods Study. Sustainability, (January), 1-20. https://doi.org/10.3390/su10010207

Nakpodia, F., \& Adegbite, E. (2018). Corporate governance and elites is. Accounting Forum, 42(1), 17-31. https://doi.org/10.1016/j.accfor.2017.11.002

Pessina, E. A., \& Sicilia, M. (2012). Budgeting and Rebudgeting in Local Governments:Siamese Twins? Public Administration Review, $x x, 1-10$. https://doi.org/10.111/j.1540-6210.2012.02590.x.Budgeting

Republik Indonesia. Peraturan Pemerintah Republik Indonesia Nomor 45 Tahun 2017 Tentang Partisipasi Masyarakat Dalam Penyelenggaraan Pemerintahan Daerah.

Republik Indonesia. Peraturan Pemerintah Republik Indonesia Nomor 58 Tahun 20005 Tentang Pengelolaan Keuangan Daerah.

Sapri, Mustanir, A., Ibrahim, M., Adnan, A. A., \& Wirfandi. (2019). Peranan Camat dan Partisipasi Masyarakat Dalam Musyawarah Perencanaan Pembangunan di Kecamatan Enrekang Kabupaten ENrekang. Jurnal MODERAT, 5(2), 33-48.

Shaidra, A. (2020). Ada cemas dana dipangkas. Majalah Tempo, https://majalah.tempo.co/read/ekonomi-dan-bisnis/1.

Sofianto, A. (2017). Kontribusi Dana Desa Terhadap Pembangunan dan Pemberdayaan Masyarakat di Kebumen dan Pekalongan. Matra Pembaruan, 1(1), 23-32.

Sohrabi, C., Alsafi, Z., Neill, N. O., Khan, M., Kerwan, A., Al-jabir, A., ... Agha, R. (2020). World Health Organization declares global emergency: A review of the 2019 novel coronavirus ( COVID-19 ). International Journal of Surgery, 76(February), 71-76. https://doi.org/10.1016/j.ijsu.2020.02.034

Syailendra, G. D., \& Hamidah. (2019). MAKNA PROFESIONALISME BAGI DIRI PETUGAS PEMERIKSA PAJAK. Jurnal Akuntansi Multiparadigma, 1O(4), 241-261.

Trenggalek, P. K. (2020). Pemerintah kabupaten trenggalek melakukan efisiensi anggaran menyusul adanya beberapa kebijakan dari pemerintah 
pusat ditengah penanganan pandemi covid-19.

Weele, A. J. V. A. N., \& Raaij, E. M. V. A. N. (2014). THE FUTURE OF PURCHASING AND SUPPLY MANAGEMENT RESEARCH : ABOUT RELEVANCE AND RIGOR. The Future of PSM Research, 5O(1), 56-72.

Widyaningrum, W., Setiawan, D., \& Brahmana, R. K. (2019). Factors Affecting Rebudgeting in Local Government: From Organizational Feature to Political Variables. International Journal of Economics and Management, 13(October 2018), 139-152.

Yanuarisa, Y., Rosidi, \& Irianto, G. (2011). Fenomenologi Transedental Dalam Transparansi dan Akuntabilitas Performance Based Budgeting. Jurnal Aplikasi Manajemen, 12(2), 208-221. 